assessing individuals before giving them training. Mr. Viteles does not suggest that training is the panacea for unemployment, but he does maintain that when the more fundamental problems are solved, and further knowledge of occupational trends is available, it will be of ever-increasing value.

\section{Mimicry in Animals}

ON November 24, Prof. G. D. H. Carpenter, Hope professor of zoology in the University of Oxford, delivered the second part of his inaugural lecture (see Nature of November 25, p. 813). Dealing with the imitation of inedible or distasteful by edible species (Batesian mimicry), and the resemblances between inedible models (Müllerian mimicry or synaposematism), he laid stress on the fact that edibility and the reverse are not absolute but relative. The results of experiment accord well with theory, as is shown by Prof. Carpenter's own observations with monkeys, Moreton-Jones's with birds and Cott's with frogs. The fact of preferential feeding is well established. The polymorphism often shown by mimetic species is also in accordance with theory. It is evident that while models would gain, on the principle laid down by Müller, by diminishing diversity between their appearances, mimics on the other hand would find advantage by increasing it. Mimicry cannot be simply the result of coincidence due to a limited range of colour, nor can it be accounted for by supposing a parallel drift of variation. Mimicry might deceive an artist, not an anatomist. The only available key to the diverse phenomena of mimicry is the principle of natural selection.

\section{Evolution in the Light of Past Ages}

STUDENTs of life in the past have followed with interest a course of three lectures on "Palæobiology and Evolution", which have just been given at University College, London, by Prof. O. Abel, of the University of Vienna. The first lecture, delivered on November 24, dealt with the methods and aims of palæobiology. Prof. Abel stressed the importance of regarding even fossil animals as living creatures. Leaving aside the problems of phylogeny, with which palæontologists have so largely concerned themselves, he concentrated his discussion on what might perhaps be called the ecology of past ages. He showed how, from such evidences as tracks in the sand, fractured or diseased bones or small invertebrates imprisoned in amber, one can piece together a picture of the conditions of life and habits of animals now known only by their fossil remains. His second lecture was entitled "Palæobiology and Phylogeny" ; in the third, a lifepicture of the fauna of the Great Ice Age was presented.

\section{Acquisitions at the British Museum (Natural History)}

Major P. H. G. Powexi-Cotton has presented to the Department of Zoology a collection of mammals, mostly large ungulates (including skins and skeletons), shot in the Sudan by him during his recent expedition in North-East Africa. This series of specimens is of exceptional interest as each one has a perfect skeleton, including a Sudani Giant Eland. There have been two notable additions in the Department of Geology ; one, a slab, $8 \mathrm{ft}$. high, containing a reconstructed group of palm leaves, from the Tertiary beds of Italy, presented by the Right Hon. Lord Rothschild; the other a small but select assemblage of British fossil vertebrates, collected by Mr. S. L. Wood, and presented by him, including Eocene mammalian and bird remains from the Isle of Wight and Liassic reptiles from Dorsetshire and Yorkshire. Presents to the Department of Minerals include crystallised sprays of native gold from the City Deep mine, Witwatersrand, from the directors of the Central Mining and Investment Corporation, Ltd.; and tektites (billitonites) from Billiton, Dutch East Indies, presented by Engineer R. J. van Lier. A large series of rocks and minerals has been collected for the Department by Mr. W. Campbell Smith in the United States and in Canada, and material was also selected by him from the duplicates of the United States National Museum and the United States Geological Survey.

Col. A. H. Wolley-Don has presented his collection of British brambles (Rubus) to the Department of Botany. It comprises about one thousand sheets, most of which have been examined by critical workers in the group. Most of the specimens are from Cheshire. The plants collected by Mr. T. G. Tutin on the recent Cambridge expedition to British Guiana under Dr. G. S. Carter have been presented to the Department. There are about 900 specimens, well preserved and in good series, principally from the region of the Cuyuni River. A further 230 flowering plants from Tanganyika territory have been purchased from H. J. Schlieben. These have been identified by Dr. J. Mildbraed of Berlin.

\section{Engineering Exhibition at Cardiff}

THE Engineering Exhibition at Cardiff on November 22-December 2, held under the auspices of the South Wales Institute of Engineers, was the twelfth annual exhibition run by the Institute and, notwithstanding the depression in the mining industry of South Wales, the exhibitors staged some excellent examples of the latest developments of machinery and plant. Among the new features in the exhibits this year was a display by the Department of Scientific and Industrial Research. This exhibit included material for the survey of the coal seams of Great Britain which is being undertaken to determine their physical and chemical characteristics ; a model coal cleaning plant in operation; exhibits illustrating recent progress in the carbonisation of coal and hydrogenation; pulverised fuel and the suspension of coal in oil. This combined research exhibit must have been of great value to those who are responsible for the mining industry in South Wales. Other special features of the exhibition were coal breaking and dry cleaning plants, steel girder arches and continuous steel lining for underground roads, electric plant, switchgear and mine signalling apparatus, woodwork machinery plant, mechanical stokers, electric welding plant, steel pit props, coal tar products for use on roads, an oxygen 'cutting' 